\title{
REPRODUCTIVE PARAMETERS OF NATIVE SOWS IN SELECTED AREA OF BANGLADESH
}

\author{
M. A. Motaleb ${ }^{1}$, M. K. Chowdhury ${ }^{2}$, M. A. Islam ${ }^{2}$, J. U. Ahmed ${ }^{1}$ and M. M. U. Bhuiyan ${ }^{1 *}$ \\ ${ }^{1}$ Department of Surgery and Obstetrics, Faculty of Veterinary Science, Bangladesh Agricultural University, \\ Mymensingh-2202, Bangladesh, ${ }^{2}$ DLS, Krishi Khamar Sarak, Farmgate, Dhaka 1215, Bangladesh
}

\begin{abstract}
Reproductive performance is considered as one of the important factors affecting the productivity and economy of the pig farms. The objective of the study was to determine the reproductive parameters of gilts and sows by direct interview method using a pretested questionnaire in selected area of Bangladesh. A total of 20 pig farms having 60 gilts and 27 sows were included in this investigation. The present study revealed that, in native female pigs, the age at puberty was $229.0 \pm 16.7$ days, the oestrous cycle length was $22.2 \pm 1.2$ days, the oestrous duration was $37.9 \pm 14.2$ hours, the gestation length was $113.5 \pm 1.0$ days, the interval between farrowing and onset of oestrus was $62.9 \pm 11.9$ days and the number of piglets born per native sow was $5.25 \pm 2.3$. It was also found that the first service pregnancy rate was $71.7 \%$ and the number of services required for each pregnancy was 1.3. The highest proportion of pigs was detected in oestrus by observing stand to be mounted by boars. It is concluded that reproductive parameters of native sows need to be improved for better production.
\end{abstract}

Key words: Reproductive parameters, Native sow, Mymensingh

\section{INTRODUCTION}

Pig has high reproductive performance with excellent prolific nature and fertilization capacity (Peltoniemi et al., 2007). It is considered as the richest source of animal protein at a lower cost for the peoples who consume pork. In most of the areas of Rangamati and Khagrachari districts, rearing of pig is done by indigenous peoples who do not know the efficient rearing of pig for better reproductive performance. In Bangladesh sweepers and indigenous communities are the main rearer of pig for using pork during the Christmas and marriage period. Therefore, pig rearing is important for the communities who consume pork.

There are several measures of reproductive performance of sow including farrowing rate, litter size at birth and fertility index. The goal of reproductive performance is to have 2.0 litters per female annually with an average of 8.0 pigs per litter at weaning, that is, a total of 16 pigs weaned per year for each female maintained in the herd (Day, 1974). A recent report on production system of swine in the rural area of Rangamati and Khagrachari districts of Bangladesh demonstrated that the average litter size, birth weight, post-weaning weight and weaning period were 9.3, $1.72 \mathrm{~kg}, 9.0 \mathrm{~kg}$ and 40.8 days respectively (Hossain et al., 2011). This low reproductive performance of sow in Bangladesh is due to inefficient management of rearing system.

Therefore, reproductive performance of sow is important to produce increase amount of pork in Bangladesh. Moreover, for the profitable swine farming in Bangladesh, efficient management of reproductive parameters is important. However, very limited study has been conducted on evaluation of reproductive performances of native pigs of Bangladesh (Sinha, 2012). Therefore, it is essential to determine the present reproductive performance of native swine of Bangladesh. The present study was to determine the common reproductive parameters of native sows in selected area of Bangladesh.

\section{MATERIALS AND METHODS}

\section{Preparation of questionnaire and data collection}

The questionnaire was prepared according to the objective of the investigation and was designed in a simple way so that the farmers could understand easily. The questionnaire included questions to collect information on age at puberty, oestrous cycle length, oestrous duration, prominent oestrous signs, gestation period, number of piglets born per sow, parity of sows, interval between farrowing and onset of oestrus and number of services required for each pregnancy. The investigator personally visited the farms of selected study area. Direct interview method was used for collection of information. Information given by pig farmers was recorded on questionnaire.

*Corresponding e-mail address: mmubhuiyan@gmail.com

Copyright (c) 2014 Bangladesh Society for Veterinary Medicine

All rights reserved 0313/2014 


\section{A. Motaleb and others}

\section{Study area, period and study population of pigs}

Pig farms of Haluaghat, Dubhaura, Mymensingh Sadar and Muktagachha upazila of Mymensingh district were selected for the study during the period from December 2012 to May 2013. A total of 20 pig farms having 298 pigs (135 pigs from 14 farms of Haluaghat uapazila, 130 pigs from 1 farm of Dubhaura Upazila, 18 pigs from 2 farms of Mymensingh Sadar upazila and 15 pigs from 3 farms of Muktagacha upazila). Among total pigs, 60 were breedable females (sows), 27 were breedable males (boars) and 211 were piglets. The number of pigs per farm varied from 2 to 130 .

\section{Management of pigs}

The sows were reared either traditionally, extensively, semi-intensively or intensively by the farmers. In extensively managed small holding farms, most sows were under grazing freely daily. All sows had free access to drinking water. There was no restriction of suckling by piglets. Weaning is occurred naturally in these sows. Boars and sows were kept together and natural mating occurred among them. They were kept in open houses made by bamboo. By day, sows were kept free and they took food from here and there. In semiintensive system, floor of some houses was made of concrete and some were made of sand. Most of the houses of pigs were not clean and the surrounding of house was not clean also. The houses of sows were located near the drain orgarbage. Farmers are not careful of the general health condition of swine. Some farmers practiced deworming (12 farms out of 20) regularly but no vaccinations were in practice there. At night, they were kept in houses. Sows were fed with rice husk, rice polish, rice gruel and waste product of hotels. In traditional rearing system sows are tied by rope or chain with a tree or thumb and feed was supplied to them under tied condition. Piglets are free range until matured. No extra care or management was done for them. But in intensive rearing system, matured and young pigs were housed separately and fed them separately. They were protected from extreme weather and extra care was taken for pregnant sows. Sometimes breeding boar was house separately.

\section{Determination of reproductive parameters of sows}

Age at puberty was determined by calculating intervals from birth to first detected oestrus of individual gilt and was expressed in days. Oestrous cycle length was determined by calculating intervals between two consecutive oestruses and was expressed in days. Oestrous period was determined by calculating intervals from the onset of oestrus to the end of oestrus and was expressed in hours. Prominent oestrus signs of sows were determined by observing behavioral and physical signs of gilts and sows by the farmers. Gestation length of sows was determined by calculating the interval between the date of last service and the date of parturition and was expressed in days. Number of piglets born per sow was determined by counting the numbers of live and dead fetuses delivered by individual sows. Parity of sows was determined by recording the number of parturition occurred by individual sows and farmers were interviewed to know this. Interval between farrowing and onset of oestrus in sows was determined by calculating by the interval between date of parturition and date of onset of oestrus and was expressed in days. Number of required services for each pregnancy was determined by interviewing the farmers and by calculating the number of services required for each pregnancy.

\section{Statistical analysis}

The collected data were entered into the Excel datasheet and descriptive statistics were performed. The values for age at puberty, oestrous cycle length, oestrous period, prominent oestrous signs, gestation length, number of piglets born per sow, interval between farrowing and onset of oestrus, number of services for each pregnancy were expressed as mean \pm standard deviation.

\section{RESULTS ANDDISCUSSION}

The mean age at puberty, oestrous duration, oestrous cycle length, gestation length, interval between farrowing and onset of oestrus, and number of piglets born per sow in native sows were $229.0 \pm 16.7$ days, $37.9 \pm 14.2$ hours, $22.2 \pm 1.2$ days, $113.5 \pm 1.0$ days, $62.9 \pm 11.9$ days and $5.25 \pm 2.3$, respectively (Table 1 ). The average age at puberty of native sows was 229 days (about 7.5 months). Similarly, the first oestrus and ovulation normally occurred between 5 and 8 months of agein European breeds (Christenson and Ford, 1979; Hughes, 1982). However, the age at puberty of present study is a little bit lower than that of a previous study where the age 
at puberty was 254.5 days (Sinha, 2012) and a little bit higher than that of a previous study where the age at puberty was 204 to 206 days (Sterning et al., 1998; Tummaruk et al., 2003). Contrasting to the present and previous findings, occurrence of puberty at the age of 3 months has been reported in Chinese Meishan breed elsewhere (Cheng, 1983). The variations at the age of puberty among different studies may be due to difference in environment, feeding and management practice.

Table 1. Reproductive parameters of native sows in selected areas of Bangladesh

\begin{tabular}{|llll|}
\hline Parameter & Mean \pm SD & Minimum & Maximum \\
\hline Age at puberty (days) & $229.0 \pm 16.7$ & 187 & 286 \\
Oestrus duration (hours) & $37.9 \pm 14.2$ & 12 & 72 \\
Oestrous cycle length (days) & $22.2 \pm 1.2$ & 20 & 25 \\
Gestation length (days) & $113.5 \pm 1.0$ & 111 & 115 \\
Interval between farrowing and onset of oestrus (days) & $62.9 \pm 11.9$ & 39 & 87 \\
Number of piglet born in per sow per pregnancy & $5.3 \pm 2.3$ & 3 & 13 \\
\hline
\end{tabular}

The mean oestrous cycle length in native sows was found $22.2 \pm 1.2$ days. Similarly, the oestrous cycle length was 21 days (Singleton and Diekman, 1990). In the present study, the mean duration of oestrus in native sows was 37.9 hours. Similarly, Singleton and Diekman (1984) reported that duration of oestrus or heat is variable which may last only 12 hours in gilts or up to 60 hours or more in sows. Contrasting to the present finding, Bennemann et al. (2004) reported that the oestrous duration in sows was 59.8 hours which ranged from 24 to 120 hours. The variation in duration of oestrus among studies may be due to environment, feeding and management practices.

The mean gestation length was 113.5 days. Similarly, average gestation length of 114 days has been reported elsewhere (Pitcher and Springer, 1997). Moreover, Cole and Foxcroft (1982) reported a gestation length of 114 days in domestic sows and 119 days in wild sows.

The mean interval between farrowing and onset of oestrus in native sows was 62.9 days. Sows generally lack of cyclic ovarian activity during the lactation period (Melampy et al., 1966; Crighton and Lamming, 1969). Nevertheless, in the present study, no weaning practice was done and it may result in having long interval between farrowing and onset of oestrus. This emphasizes the importance of practicing weaning of piglets for shortening of postpartum anoestrus period in native pigs.

The mean number of piglet production was 5.3. Contrasting to the present finding, Halina et al. (1993) obtained 12.2 piglets per litter after evaluating 98 farrowings. Cole and Foxcroft (1982) also reported to have 12 piglets per litter in domestic sows and 5 piglets in wild sows. The variation between studies may be due to lower body weight and smaller size of the sows in present study compared to previous studies.

The highest proportion of sows $(30.0 \%)$ was detected in oestrus by observing stand to be mounted by boars and the lowest proportions of sows $(6.7 \%)$ were detected in oestrus by off feeding and aggressiveness of sows.

Table 2. Number of services required for each pregnancy in sows

\begin{tabular}{|lll|}
\hline Number of service for each pregnancy & Number $(\%)$ of sows & Mean \\
\hline 1 & $43(71.7)$ & 1.3 \\
\hline & $17(28.3)$ & \\
\hline
\end{tabular}




\section{A. Motaleb and others}

The mean number of services required for each pregnancy in indigenous sows was 1.3 and first service pregnancy rate was $71.7 \%$ in native sows (Table 2). Similarly, pregnancy rate $(71.9 \%)$ has been documented in swine received natural service (Cole and Foxcroft, 1982). A number of factors contribute to the success or failure of breeding in sows. Age, mode of insemination and the number of insemination attempts have been shown to affect rates of successful pregnancy in swine (Scofield and Penny, 1969; Wrathall, 1975; Hughes and Varlet, 1978; Flowers and Esbenshade, 1992). However, in the present study, the author sued very few numbers of sows for investigation and the exact age of sows was not known due to lack of records.

\section{ACKNOWLEDGEMENTS}

The authors are indebted to farmers of the study areas for their cordial co-operation to perform the research work.

\section{REFERENCES}

1. Bennemann PE, Milbradt E, Diehl GN, Weber D, Schimidt ACT, Bernardi ML and Pitkjanen LG (2004). Reproductive performance of sows submitted to intrauterine insemination at different pre-ovulatory intervals. Animal Reproduction Science 1: 106-110.

2. Cheng PL (1983). A highly prolific pig breed of China. The Taihu breed Pig: News and Information 4: 407426.

3. Christenson RK and Ford JJ (1979). Puberty and estrus in confinement reared gilts. Journal of Animal Science 49: 743-751.

4. Cole DJA and Foxcroft GR (1982). Control of pig reproduction. Butterworth, London.

5. Crighton DB and Lamming GE (1969). The lactational anestrus of the sow: The status of the anterior pituitary-ovarian system during lactation and after weaning. Journal of Endocrinology 43: 507-512.

6. Day BN (1974). Reproductive problems in swine. Beltsville Symposia in Agricultural Research. Animal Reproduction. Allanheld, Osmum and Co. Publishers Inc.

7. Flowers WL and Esbenshade KL (1992). Optimizing management of natural andartificial matings in swine. Journal of Reproduction and Fertility 48: 217-228.

8. Halina M, Zaleski, Roger R and Hacker (1993). Variables related to the progress of parturition and probability of stillbirth in swine. Canadian Veterinary Journal 34: 109-113.

9. Hossain ME, Chakma S, Khatun MM, Hasanuzzaman M, Miah MY and Biswas MAA (2011). Production systems of swine in the rural areas of Rangamati and Khagrachari districts of Bangladesh. Bangladesh Journal of Animal Science 40 (1-2): 28-33.

10. Hughes PE (1982). Factors affecting the natural attainment of puberty in the gilt. Control of Pig Reproduction pp: 93-116.

11. Hughes PE and Varlet M (1978). Reproduction in the Pig. Butterworth Group, Woburn, MA.

12. Melampy RM, Henricks DM, Anderson LL, Chen CL and Schultz JR (1966). Pituitary follicle-stimulating hormone and luteinizing hormone concentrations in pregnant and lactating pigs. Endocrinology 78: 801-809.

13. Melampy RM, Henricks DM, Anderson LL, Chen CL and Schultz JR (1966). Pituitary follicle-stimulating hormone and luteinizing hormone concentrations in pregnant and lactating pigs. Endocrinology 78: 801-809.

14. Peltoniemi OAT, Oliviero C, Halli O and Heinonen M (2007). Feeding affects reproductive performance and reproductive endocrinology in the gilt and sow. Acta Veterinaria Scandanavica 49 (Suppl 1): S6.

15. Pitcher P and Springer S (1997). Gestation in Swine. School of Veterinary Medicine, University of Pennsylvania, p. 2.

16. Scofield AM and Penny RHC (1969). An analysis of some factors affecting performance in a large pig herd: Annual production of pigs per sow British Veterinary Journal 125: 3-6.

17. Singleton W and Diekman M (1984). Reproductive physiology and anatomy of the sow. Purdue University, Department of Animal Sciences, USA.

18. Singleton W and Diekman M (1990). Reproductive physiology and anatomy of the sow. Purdue University, Department of Animal Sciences, USA.

19. Sinha RC (2012). Reproductive parameters of native sows in Bangladesh, MS Thesis, Department of Surgery and Obstetrics, Bangladesh Agricultural University, Mymensingh, Bangladesh. 
20. Sterning M, Rydhmer L, Eliasson L and Selling L (1998). Relationships between age at puberty and interval from weaning to estrus and between estrus signs at puberty and after the first weaning in pigs. Journal of Animal Science 76: 353-359.

21. Tummaruk P, Suwimonteerbutr J and Laotanakit A (2003). The impact of indoor temperature and humidity on puberty attainment in gilts. The 11th international symposium of the world association of veterinary laboratory diagnosticians and OIE seminar on biotechnology, Department of Obstetrics, Gynaecology and Reproduction, Chulalongkorn University, Bangkok, Thailand, p. 153.

22. Wrathall AE (1975). Reproductive disorders in pigs. Commonwealth Agricultural Bureau, Slough, England. 